DOI 10.31558/2075-2970.2019.38.7

УДК УДК 811,111 '371.5

ORCID ID: 0000-0001-6998-7788

(C) І. М. Запухляк

(м. Вінниця)

\title{
СТРУКТУРНІ ОСОБЛИВОСТІ ФРАЗЕОЛОГІЧНИХ ОДИНИЦЬ З ЛЕКСИЧНИМ КОМПОНЕНТОМ «ВОДА» В УКРАЇНСЬКІЙ МОВІ TA «WATER» В АНГЛІЙСЬКІЙ МОВІ
}

\begin{abstract}
Анотація. У статті досліджуються структурні особливості фразеологізмів з лексичним компонентом «вода» в українській та «water» в англійській мовах, описані їхні семантико-граматичні розряди, виокремленні подібні та відмінні структури в англійській та українській мовах. У дослідженні використано такі методи досліджень як метод суцільної вибірки, методи аналізу та синтезу для встановлення спільних та відмінних рис фразеологізмів англійської та української мов, описовий метод та метод дистрибутивного аналізу. Виділено фразеологічні одиниці рівня лексеми, словосполучення та речення, описано їхні види. Встановлено, що фразеологізми лексичного рівня притаманні лише англійській мові, де відповідні слова стають лексемами вторинної номінації, набуваючи ідіоматичного значення шляхом метафоризації. Фразеологізми рівня словосполучення, в свою чергу, поділяються на субстантивні, ад'єктивні, дієслівні та адвербіальні семантико-структурні розряди, залежно від значення фразеологізму та граматичної функції у реченні. В статті описано пряму залежність окремих структурних типів фразеологізмів від структури мови, що впливає на позиційність складових елементів в межах конструкції, на особовість / безособовість структури, виказує прояви конверсійності мовних одиниць, або надає можливість регулювання семантико-синтаксичними відношеннями конституентів фразеологічних одиниць за допомогою флексій. 3'ясовано залежність деяких структурних типів від лінгвокультурних традицій носіїв досліджуваних мов, зокрема тенденцію українських фразеологічних одиниць до імпліцитності стрижневої ознаки компаративних фразеологічних утворень та схильність до формування фразеологічних одиниць у дійсному способі. Зазначено різні підходи у лексикографічних традиціях дослідників аналізованих мов, що також дотично впливає на можливість виокремлення певних структурних груп.

Ключові слова: фразеологізм, субстантивний фразеологізм, ад’єктивний фразеологізм, адвербіальний фразеологізм, дієслівний фразеологізм.
\end{abstract}

Iryna Zapukhlyak STRUCTURAL PECULIARITIES OF IDIOMS WITH THE LEXICAL COMPONENT 'ВОДА' IN THE UKRAINIAN LANGUAGE AND THE COMPONENT 'WATER' IN THE ENGLISH LANGUAGE

Abstract. The article dwells upon structural features of the idioms with the lexical component 'ВОДА' in the Ukrainian language and the lexical component 'WATER' in the English language. The topicality of the article is stipulated by the scholars' attention to the contrastive researches of the idioms in English and Ukrainian. The aim of the article is to define and describe the grammatical features of the idioms with the component 'ВОДА' in Ukrainian and the component 'WAТЕR' in English. The article focuses on 382 idioms (251 English idioms with the component 'WATER' and 131 Ukrainian idioms with the component 'ВОДА'). The research resorts to the following research methods: a continuous sampling method, methods of analysis and synthesis; a descriptive method and the distributive method. The results of the analysis show the existence of isomorphic structural groups of the idioms with the component 'ВОДА' in the Ukrainian language and the component 'WATER' in the English language apart from the allomorphic structural models, which exists only in one of the languages under consideration. The allomorphic group of the English language is represented by 
compound words, as the meaning of the lexeme becomes the unit of the second nomination, acquiring metaphoric meaning. The isomorphic groups are word combinations and sentences. The most productive group of the idioms with the component 'ВОДА' in Ukrainian and the component 'WAТЕR' in English are word combinations which can be divided into substantive, adjective, verbal, and adverbial idioms.

Key words: idiom, substantive idiom, substantive idiom, adjective idiom, verbal idiom, adverbial idiom.

\section{1. Ветуп}

Сучасні мовознавчі дослідження приділяють значну увагу фразеологічним одиницям як прояву національної своєрідності та неповторності. Об'єктом лінгвістичних розвідок вже неодноразово виступали фразеологізми з різноманітними компонентами, створюючи грунтовну методологічну базу для подальших розвідок, зокрема I. Задорожна досліджує німецькомовні фразеологічні одиниці (далі ФО) з компонентами іменниками "spaß", "gnade" та "freude" (Задорожна, 2014), Л. О. Лисенко приділяє увагу вивченню фразеологізмів із компонентом «вогонь» (Лисенко, 2016), Ю. В. Білоус вивчає ФО з соматичним компонентом у німецькій мові (Білоус, 2014), а В. В. Хмара досліджує фразеологізми з соматичним компонентом вухо (Хмара, 2015). Дослідження Д. Маркової зосереджено на ФО з компонентом «серце» (Маркова, 2017), натомість, Р. О. Ніколайчук розглядає фразеологізми із компонентом «грошова одиниця» (Ніколайчук, 2014). Однак фразеологізми з лексичним компонентом «вода» та «water» ще не ставали предметом окремого дослідження.

У роботі використовуються такі методи як метод суцільної вибірки, методи аналізу та синтезу для встановлення спільних та відмінних рис фразеологізмів англійської та української мов, метод дистрибутивного аналізу, а також описовий метод.

Матеріалом дослідження є 382 фразеологічні одиниці, дібрані методом суцільної вибірки 3 сучасних фразеологічних словників (251 фразеологізм англійської мови 3 компонентом «water» та 131 фразеологізм української мови з компонентом «вода»).

Мета дослідження - встановити ізоморфні та аломорфні характеристики у домені структури ФО з лексичним компонентом «вода» в українській мові та «water» в англійській мові.

Об’єктом дослідження є ФО з лексичним компонентом «вода» в українській мові та «water» в англійській мові.

Предмет - структурні особливості ФО з компонентом «вода» в українській мові та «water» в англійській мові.

2. Виклад матеріалу. Оточуючий світ впливав на життя людей з прадавніх часів. Невід'ємною його частиною та найважливішим елементом для життя людства є вода. Не дивно, що слова «вода» та «water» стали компонентами різноманітних фразеологізмів, наприклад: англ. to swim between two waters 'займати нейтральну позицію', a toe in the water 'спроба зробити щось, чого раніше не робив', ebb-water 'нестача грошей', christened in pump-water 'червоношкірий', what comes with the wind goes with the water 'легко прийшло, легко пішло', укр. сьома вода на киселі 'далекий родич', вудити рибу в каламутній водi 'використовувати будьякі обставини на свою користь'.

Присутні в обох мовах дослідження, ФО з компонентом «вода» в українській мові та «water» в англійській мові проявляються в різних структурно-граматичних формах. Аналіз емпіричного матеріалу засвідчує, що ФО з лексичним компонентом «вода» в українській мові та «water» в англійській мові є одиницями різного рівня: 1) лексичного - складні слова (прояв- 
ляються лише на матеріалі дослідження англійської мови), зокрема англ. jerk-water 'неважлива особа', 2) синтаксичного - а) словосполучення (англ. get in deep water 'потрапити у скрутну ситуацію', укр. як у воду канути 'безслідно зникнути') та б) речення (наприклад англ. тапу drops of water will sink a ship 'багато маленьких кроків приведуть до значного результату’, укр. як хто линув водою 'хто-небудь дуже вражений, приголомшений чимось').

2.1 ФО 3 компонентом «вода» в українській мові та «water» в англійській мові рівня словосполучення. Результати аналізу засвідчують, що найпродуктивніші ФО з лексичним компонентом «вода» в українській мові та «water» в англійській мові $€$ фразеологізми рівня словосполучення. Можна припустити, що це пов'язано з тим фактом, що граматична структура такого рівня дає можливість висловити необхідну інформацію за допомогою фрази, яка $\epsilon$ досить «економною» за розміром. Оскільки переважна більшість фразеологізмів має конотативне, семантично ємне значення, відоме члену мовної спільноти, мовець має змогу досягнути своєї мети, використовуючи відносно короткі ФО замість розлогих речень.

Автор поділяє думку М. Ф. Алефіренко стосовно того, що «Оскільки ... фраземи співвідносяться з лексико-граматичними класами слів, то їх можна згрупувати умовно в такі семантико-граматичні розряди: субстантивні, ад'єктивні, дієслівні, адвербіальні та інтер'єктивні» (Алефіренко, 1987, с. 46). Взявши ФО з лексичним компонентом «вода» в українській мові та «water» рівня словосполучення як субстантивні, дієслівні та ад'єктивні фразеологізми. Розглянемо детальніше кожен з цих розрядів.

2.1.1 Дісслівні ФО з компонентом «вода» в українській мові та «water» в англійській мові. Дієслівні фразеологізми виступали предметом окремих розвідок, зокрема Д. Є. Ігнатенко досліджувала дієслівні фразеологізми на позначення інтенсивності дії та стану, (Ігнатенко, 2013), А. М. Троцюк досліджувала ФО з соматичним компонентом “hand" (Троцюк, 2010), a I. М. Кучман приділяв увагу дієслівним фразеологічним одиницям каузативної семантики (Кучман, 2007). М. Т. Демський вказує, що до дієслівних відносяться ФО з узагальненою семантикою процесуальної ознаки, об'єктивованою в дієслівних категоріях виду, стану, способу, особи та часу (Демський, 1984, с. 26-28). Проведений аналіз ФО з лексичним компонентом «вода» в українській мові та «water» в англійській мові дозволяє стверджувати, що найчисленнішим в обох досліджуваних мовах семантико-граматичним розрядом ФО рівня словосполучення є розряд дієслівних фразеологізмів.

Критеріями класифікації є частиномовна приналежність компоненту та його позиційність структурі фразеологізму. Структурні моделі представлені формулами, де N - Noun, NP Noun Phrase, VP - Verb Phrase V - Verb, Adj. - Adjective, Adv. - Adverb, Art. - Article, Prep. Preposition, Pron. - Pronoun, Conj. - Conjunction, Num. - Numeral, Part. - Paticiple. Іменникові фрази можуть бути різного виду, включаючи такі компоненти як прикметник, дієприкметник, числівник, прислівник, артикль, займенник та іменник. Дієслівні фрази можуть включати прислівник, прийменник, а також іменник.

Дієслівні фразеологічні одиниці є найчисленнішими в обох досліджуваних мовах. Весь емпіричний матеріал можна згрупувати у 5 структурних моделей англійської мови та 6 структурних моделей в українській мови. Необхідно зазначити, що оскільки в українській мові відсутні артиклі, при виокремленні ізоморфних для двох мов структурних моделей наявність артиклів ігнорується, оскільки останні не є представниками повнозначних частин мови і не відіграють ролі у синтагматичному поєднанні слів. 
2.1.1.1 Ізоморфною групою в обох досліджуваних групах є структурна модель $\mathbf{V}+\mathbf{N}$ / $\mathbf{N P}+$ Prep. + N / NP, яка $\epsilon$ найпродуктивнішою структурною моделлю ФО 3 компонентом «water» в англійській мові, де дієслово має додаток, що виражається іменником, якому можуть передувати артикль, займенник, прикметник чи числівник, а після додатка вживається прийменник. Наприклад: англ. to throw the baby out with the bathwater 'позбуватися чогось цінного, викидаючи непотрібне', to hold smb. with his bill in the water 'тримати когось у напрузі', to lay hairs in the water 'починати діяти', to put water in your wine 'бути поміркованим', to carry hot water with one 'спричиняти сварки'. В українській мові - це лити воду на млин 'допомагати, сприяти чомусь', скаламутити воду в кринищі 'вносити неспокій', ловити рибу в каламутній водi ‘використовувати будь-які обставини, хитрувати для власної вигоди'. Це можна пояснити подібними граматичними правилами побудови словосполучень та речень, оскільки вживання прямого додатку є притаманним обом досліджуваним мовам.

2.1.1.2 Другою за продуктивністю в англійській мові є структурна модель V + Prep. + N / NP, що також характерна в українській мові, відображаючи вживання непрямого додатку після дієслова. Прикладами таких фразеологізмів є: англ. to go off someone like water off a duck's back 'не мати жодного ефекту на когось', to wamble like an eel in the water 'дуже звиватися', to sail in troubled waters 'скористатися заплутаною ситуацією', to go down the water 'занепадати', to be under water 'мати фінансові труднощі', to take in water 'мати недоліки', укр. виводити на свіжу воду 'виявляти чиюсь непоряднісь', перебиватися з хліба на воду 'ледве справлятися з матеріальними труднощами', втопити в ложиі води 'завдавати великих прикростей'.

2.1.1.3 Ізоморфною структурною моделлю аналізованих фразеологізмів є структурна модель V + N / NP, в якій використовуються два або три елемента. Оскільки мовець прагне до скорочення використання мовних засобів, видається логічним функціонування 'компактної' моделі, що передає фігурально переосмислену, іноді значну конотативну інформацію. Наприклад: англ. to water the corn 'запивати їжу якимось напоєм', to muddy the waters 'заплутувати справу', to tread water 'навмисно нічого не робити', укр. виварити воду 'знущатися з когось, показуючи свої примхи', каламутити воду 'навмисне робити щось незрозумілим'. Аломорфною підгрупою аналізованих одиниць в українській мові $\epsilon$ структура $\mathbf{V}+\mathbf{N}+\mathbf{N}$, що дещо розширює модель, $\mathbf{V}+\mathbf{N}$, притаманну англійській мові, за рахунок вживання додаткового іменника в орудному відмінку. Наприклад: укр. набрати шоломом води 'здобути перемогу', набирати воду решетом 'даремно щось робити'. Саме цей додатковий елемент в орудному відмінку створює необхідний, зрозумілий носію мови метафоричний образ, перетворюючи його на фразеологізм.

2.1.1.4 Ще одна ізоморфна структурна група дієслівних ФО з лексичним компонентом «вода» в українській мові та «water» в англійській мові- це структурна модель $\mathbf{V}+\mathbf{N} /$ $\mathbf{N P}+$ Conj. + N / NP, яка $\epsilon$ менш продуктивною. Це можна було б пояснити досить розлогою структурою, але в першу чергу - вживанням однорідних компонентів, з'єднаних сполучником, що не досить поширено у фразеологізмах. Наприклад: англ. to go through fire and water 'витримати всі умови', укр. пройти вогонь і воду 'подолати всі труднощі', садити на хліб та воду 'карати когось, обмежуючи в їжі', скакати у вогонь $і$ в воду 'бути готовим на будь-що заради когось'.

2.1.1.5 Досить непродуктивною ізоморфною групою аналізованих ФО є структурна модель $\mathbf{V}+\mathbf{N} / \mathbf{N P}+\mathbf{V} / \mathbf{V P}$, наприклад: англ. to bring water when the house is burned down "при- 
ходити з допомогою, коли вже запізно', to believe water will flow uphill ‘вірити всьому, що скажуть', to have other fish to fry 'мати важливіші справи', укр. пливти, куди вода несе 'пасивно підкорятися обставинам' та інші.

2.1.1.6 Незважаючи на те, що п’ять структурних моделей дієслівних ФО з лексичним компонентом «вода» в українській мові та «water» в англійській мові $\epsilon$ ізоморфними, найчисленніша група української мови - структурна модель Conj. + N / NP + V є аломорфною. Це група компаративних фразеологізмів, що розпочинаються сполучниками 'як', 'мов', 'немов', 'ніби'. Наприклад: укр. як води в рот набрати 'нічого не казати', як у воду канути 'безслідно зникнути', як у воду дивитися 'ніби знати зазделегідь'. Така група є нехарактерною для англійської мови, адже відповідно до ії граматичних правил додаток не може передувати дієслову, тому будь-які сполучникові фрази не можуть знаходитися у препозиції відносно дієслова. Фразеологізми цієї групи мають можна замінити одним дієсловом, добре відомим носію мови і адресат з легкістю його розуміє. Причому експліцитна невираженість основи порівняння жодним чином не породжує можливої альтернативності потенційних основ порівняння. На відміну від інших компаративних утворень з імпліцитною основою порівняння, для узагальненого позначення яких в західноєвропейській лінгвістиці вживається термін «відкрите образне порівняння (open simile)», що передбачає відкритий список потенційно можливих експліцитно невиражених основ, унікальність цього типу україномовних порівнянь полягає в їхній однозначності, неможливості різночитань: як у воду канути асоціюється виключно з відсутністю, а не, скажімо, з рухом вниз чи схованкою; як води в рот набрати представляється у колокації виключно з дієсловом мовчати, а не з будь-яким іншим.

В обох аналізованих мовах існують фразеологізми, що мають у складі заперечну частку, наприклад: англ. not to care a cup of cold water 'взагалі не турбуватися', not to have both oars in the water 'поводитися дивно, нераціонально', not (to) hold water 'бути неправильним', укр. ні до холодної води не братися 'нічим не займатися'. Більшість з цих фразеологізмів не вживаються без заперечної частки, яка має значний вплив на значення фразеологізму, додаючи негативу до його значення, адже висловлює несхвалення, засудження певної поведінки.

Квантитативні особливості структурних моделей дієслівних ФО з лексичним компонентом «вода» в українській мові та «water» в англійській мові представлені у Таблиці 1.

Таблиия 1

Структурні моделі дісслівних ФО з лексичним компонентом «вода» в українській мові та «water» в англійській мові

\begin{tabular}{|c|l|l|l|}
\hline № & \multicolumn{1}{|c|}{ Структурні моделі } & \multicolumn{1}{|c|}{ Англійська мова } & \multicolumn{1}{|c|}{ Украӥнська мова } \\
\hline 2.1 .1 .1 & V + N / NP + Prep. + N / NP & $45(48,91 \%)$ & $12(19,36 \%)$ \\
\hline 2.1 .1 .2 & V + Prep. + N / NP & $28(30,44 \%)$ & $16(25,8 \%)$ \\
\hline 2.1 .1 .3 & $\mathrm{~V}+\mathrm{N} / \mathrm{NP}$ & $12(13,03 \%)$ & $13(20,97 \%)$ \\
\hline 2.1 .1 .4 & $\mathrm{~V}+\mathrm{N} / \mathrm{NP}+$ Conj. + N / NP & $2(2,18 \%)$ & $4(6,46 \%)$ \\
\hline 2.1 .1 .5 & $\mathrm{~V}+\mathrm{N} / \mathrm{NP}+\mathrm{V} / \mathrm{VP}$ & $5(5,44 \%)$ & $1(1,61 \%)$ \\
\hline 2.1 .1 .6 & Conj. + N / NP + V & - & $16(25,81 \%)$ \\
\hline Разом & $92(100 \%)$ & $62(100 \%)$ \\
\hline
\end{tabular}

Проведений аналіз свідчить про існування як ізоморфних, так і аломорфних структурних моделей ФО з лексичним компонентом «вода» в українській мові та «water» в англійській мові, що може пояснюватися відмінностями у граматичних правилах, притаманних аналізованим 
мовам, а саме усталеним порядком слів у англійській мові, де дієслово завжди стоїть у препозиції стосовно прямого чи непрямого додатка. Крім того, сполучник не може передувати дієслову в англійській мові, що дозволяється граматичними правилами української мови.

\subsection{2 Ад’єктивні ФО з компонентом «вода» в українській мові та «water» в англій-} ській мові. Друга за величиною група ФО з компонентом «вода» в українській мові та «water» в англійській мові - це ад’єктивні фразеологізми. М. Ф. Алефіренко стверджує, що «... ад'єктивними називають фраземи, яким притаманне категоріальне значення атрибутивності, здатність виражати статичну ознаку предметів» (Алефіренко, 1987, с. 46). Ад’єктивні ФО можна поділити на компаративні та не компаративні, залежно від їхнього значення та структури. Розглянемо ці типи ад'єктивних ФО з лексичним компонентом «вода» в українській мові та «water» в англійській мові.

2.1.2.1 Компаративні ад'єктивні ФО з компонентом «вода» в украӥнській мові та «water» в англійській мові. Компаративні фразеологічні одиниці вже неодноразово були об'єктом досліджень. Серед інших це М. Я. Оленяк (Oleniak, 2018, 2019), К. I. Мізін (Мізін, $2013)$ О. Г. Сошко (Сошко, 2013), О. Щепка (Щепка, 2011) та інші. Особливістю компаративних ФО є наявність у їхній структурі таких компаративних елементів, як as, so, than, like в анг-

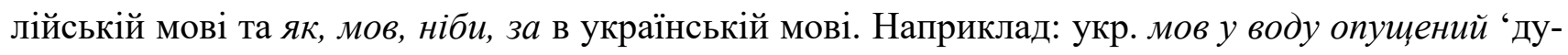
же сумний', як / мов / ніби холодною / зимною водою облитий 'розгублений, пригнічений', як крапля води 'схожий', англ. dull as ditchwater 'дуже тьмяний', like a sailor on a water-cart 'зовсім безпорадний', weak as well-water 'не міцний (про алкогольні напої)'. Як видно з прикладів, у складі таких фразеологізмів не завжди вказується ознака, яка є основою порівняння. Це можна пояснити тим, що ознака добре відома носіям мови і з часом опускається.

Поряд з тим, існує аломорфна група компаративних ад’єктивних ФО з компонентом «вода», типова лише для української мови, що має структурну модель 2.1.2.1.8 Adj. + N + Adj. + N. У ній присутня основа порівняння, однак немає сполучників, а порівняння реалізується завдяки вживанню прикметника у вищому ступені порівняння та іменника у родовому відмінку. Наприклад: укр. тихіший води, нижчий трави 'дуже скромний, непомітний'. Оскільки українська мова синтетична, система відмінків дозволяє реалізувати подібну структурну модель.

2.1.2.1.1 В результаті аналізу виявлено, що найпродуктивніша структурна модель ад'єктивних компаративних ФО з лексичним компонентом «water» в англійській мові - це структурна модель Adj. + Conj. + N / NP, де вказана основа порівняння, присутній сполучник та еталон порівняння, у складі якого є лексичний компонент «water». Наприклад: dull as dishwater 'дуже нудний', weak as well-water 'дуже слабкий', mild as maiden's water 'слабкий (про алкогольний напій)’ та інші. До цієї структурної моделі належать більшість усіх ад’єктивних компаративних ФО з лексичним компонентом «water» в англійській мові.

2.1.2.1.2 Друга за чисельністю група англійських ад’єктивних компаративних ФО з лексичним компонентом «water» - це Adj. + Conj. + N + Prep. + N / NP, наприклад: strong as / like a drink of water 'зовсім слабкий (про худорляву людину)', welcome as water into a ship 'зовсім не бажаний, неприємний'. У цій структурі присутні основа порівняння, сполучник та еталон порівняння, однак вона більша за об'ємом порівняно з попередньою структурою. Видається ймовірним, що нижча продуктивність аналізованої групи може пояснюватися саме значним обсягом фразеологізмів, що можуть бути доречними у висловленні певної думки, однак потребують часу та зусиль для вживання у мовленні. 
2.1.2.1.3 У структурній моделі 3 Conj. + N + Prep. + N / NP, що притаманна лише англійській мови, не вказується ознака, яка є основою порівняння, наприклад: англ. like a fish out of water 'розгублений', like water off a duck's back 'не маючий жодного впливу', like a yard of pump-water' дуже високий та худий'. Можливо, саме ця структурна особливість $є$ передумовою нечисленності даної групи, адже члени англійської лінгвоспільноти приписують воді різноманітні властивості. Видається логічним, що основа порівняння опускається лише в окремих ФО, значення яких добре зрозуміле носіям мови. Значення цих фразеологізмів іронічне, що може пояснювати відносну непродуктивність групи, адже мовці не можуть зловживати іронією.

2.1.2.1.4 Найменш продуктивними з ад'єктивних компаративних ФО з лексичним компонентом «water» в англійській мові є структурна модель Adj. + N + Prep. + Conj. + N, єдиним фразеологізмом цієї структури є англ. laal thowt (діалектичне little thought) on as dikewater 'взагалі неважливий' та структурна модель 2.1.2.1.5 Conj. + Adj. + Conj. + NP, представлена фразеологізмом англ. as good as ever water wet 'дуже добрий'.

2.1.2.1.6 Найпродуктивнішою структурною моделлю ад’єктивних компаративних ФО з лексичним компонентом «вода» є структурна модель Conj. + (Adj.) + (Prep.) + N + Part. Прикладами таких ФО є: укр. мов холодною зимною водою облитий 'пригнічений, приголомшений', як у воду намочений 'зажурений, злий', мов у воду опущений 'незадоволений' та інші. Ця структура є аломорфною, крім того, в результаті проведенного аналізу не виявленно жодного випадку вживання дієприкметників у англійських ФО з лексичним компонентом «water». У таких фразеологізмів оскова порівняння імпліцитною, а еталон порівняння виражений повністю усім фразеологізмом.

2.1.2.1.7 До другої за численністю структурної групи фразеологізмів з лексичним компонентом «вода» Conj. + N / NP належать синонімічні ФО, такі як укр. як капля води, як дві краплини води, як три краплі води та інші, що означають 'дуже схожий'. Як і в попередній структурній моделі, аналізовані ФО не мають основи порівняння, однак еталон представлений двома іменниками, що вживаються у називному та родовому відмінку, де головний елемент стоїть перед другорядним іменником.

2.1.2.1.9 Структурна модель Adj. + Prep. + N + Adj. + Prep. + N $€$ найменш продуктивною серед ФО з лексичним компонентом «вода», представлена фразеологізмом укр. тихіший за воду, нижчий за траву 'дуже скромний, непомітний'.

Кількісний розподіл ад’єктивних компаративних ФО з компонентом «вода» в українській мові та «water» в англійській мові представлений у Таблиці 2.

Таблиця 2

Структурні моделі ад’сктивних компаративних ФО з лексичним компонентом «вода»

в українській мові та «water» в англійській мові

\begin{tabular}{|l|l|l|l|}
\hline \multicolumn{1}{|c|}{ № } & \multicolumn{1}{|c|}{ Структурні моделі } & \multicolumn{1}{|c|}{ Англійська мова } & \multicolumn{1}{|c|}{ Украӥнська мова } \\
\hline 2.1 .2 .1 .1 & Adj. + Conj. + N / NP & $13(54,16 \%)$ & - \\
\hline 2.1 .2 .1 .2 & Adj. + Conj. + N + Prep. + N / NP & $5(20,83 \%)$ & - \\
\hline 2.1 .2 .1 .3 & Conj. + N + Prep. + N / NP & $4(16,67 \%)$ & - \\
\hline 2.1 .2 .1 .4 & Adj. + N + Prep. + Conj. + N & $1(4,17 \%)$ & - \\
\hline 2.1 .2 .1 .5 & Conj. + Adj. + Conj. + NP & $1(4,17 \%)$ & - \\
\hline 2.1 .2 .1 .6 & Conj. + N / NP + Part. & - & $6(42,85 \%)$ \\
\hline 2.1 .2 .1 .7 & Conj. + N / NP & - & $5(35,71 \%)$ \\
\hline 2.1 .2 .1 .8 & Adj. + N + Adj. + N & - & $2(14,29 \%)$ \\
\hline 2.1 .2 .1 .9 & Adj. + Prep. + N + Adj. + Prep. + N & - & $1(7,14 \%)$ \\
\hline Paзом & $24(100 \%)$ & $14(100 \%)$ \\
\hline
\end{tabular}


У результаті аналізу емпіричного матеріалу не виявлено жодної ізоморфної моделі ад’єктивних компаративних ФО з лексичним компонентом «вода» в українській мові та «Water» в англійській мові, що можливо було б пояснити їхньою різноструктурністю (наприклад в українській мові існують фразеологізми, що не мають у складі прийменників, натомість компаративність виражається завдяки прикметнику у вищому ступені порівняння) та традиційним опущенням основи порівняння у ад’єктивних компаративних фразеологізмів української мови. У результаті дослідження виявлено, що 11 (78,57 \%) компаративних ад’єктивних ФО з лексичним компонентом «вода» не мають експліцитно вираженої основи порівняння. Натомість в англійській мові на матеріалі дослідження зафіксовано лише у 4 (16 \%) компаративних ад'єктивних ФО з лексичним компонентом «water», у структурі яких відсутня експліцитно виражена ознака, за якою порівнюються об'єкти.

2.1.2.2 Некомпаративні ад'єктивні ФО з компонентом «вода» в украӥнській мові та «water» в англійській мові. Некомпаративні фразеологізми характеризують об'єкт, не порівнюючи його з іншим. Результати проведеного аналізу вказують на те, що некомпаративні ад'єктивні ФО з лексичним компонентом «вода» в українській мові та «water» в англійській мові є менш продуктивним (31,43 \% в англійській мові та 40 \% в українській мові) порівняно 3 компаративними ФО. Оскільки вода - це споконвічний, особливо важливий елемент у житті людства, її властивості настільки загальновідомі мовцям, що вона з легкістю займає позицію еталона, типового носія характерних для неї ознак. Цей факт може бути причиною того, що лексичні компоненти «вода» та «water» в обох аналізованих мовах частіше використовуються у компаративних ФО, оскільки виступають еталоном порівняння або його частиною. Всі фразеологізми цієї групи показують результат певної дії, що була спрямована на об'єкт, який характеризується цим фразеологізмом.

2.1.2.2.1 У результаті аналізу некомпаративних ад'єктивних ФО з лексичним компонентом «вода» в українській мові та «water» в англійській мові було виділено одну ізоморфну групу фразеологізмів - структурну модель Part. / Adj. + Prep. + N / NP. Прикладами таких ФО є англ. missed by the water but caught by the widdy 'той, що врятувався від утоплення, але був повішений', dead in the water 'нефункціонуючий', укр. виведений на чисту воду 'той, чию нечесність чи підступність викрили'. У цих ФО якість означуваного об’єкта пояснюється за допомогою стрижневого прикметника чи дієприкметника, а також додаткових елементів, що розширюють та доповнюють образ.

2.1.2.2.2 Найчисленнішою аломорфною групою некомпаративних ад’єктивних ФО з лексичним компонентом «water» в англійській мові, що повністю відсутня в українській мові, $є$ структурна модель $\mathbf{V}+\mathbf{V}+\mathbf{N P}+$ Prep. $+\mathbf{N} / \mathbf{N P}$, що має у структурі модальне дієслово 'could', що означає фізичну здатність, можливість щось виконати або припущення про можливість певної дії, та повнозначне дієслово і його додаток з обставиною, наприклад: англ. could drown you in a spoonful of water 'зависливий'. У двох інших двох ФО цієї структурної моделі використовується заперечна частка: англ. couldn't pour water out of a boot 'дурний', couldn't cook hot water for a barber 'зовсім поганий (про кухаря)'. В результаті аналізу не виявлено вживання підряд двох дієслів некомпаративних ад'єктивних ФО з лексичним компонентом «вода» в українській мові, оскільки в українській мові такі ФО, за наявності еквівалента, вживаються у граматичних формах, що виражають менший ступінь суб'єктивності, ніж та, яку забезпечує вживання модального дієслова в англійській мові, наприклад вона тебе в ложиі 
води втопить. Вживання дієслова втопить робить дію, описану в ФО більш реальною і правдоподібною, менш суб'єктивною, адже опускається модальне дієслово, яке виражає не саму дію, а відношення до неї мовця.

2.1.2.2.3 Дещо менш поширеною аломорфною групою ФО з лексичним компонентом «water» в англійській мові $є$ структурна модель V + V + NP + Prep. + N / NP, наприклад: англ. for all waters adaptable ‘здатний добре пристосовуватися', of the first water 'найвищої якості'.

2.1.2.2.4 Інші аломорфні групи $є$ непродуктивними ФО з лексичним компонентом «water» в англійській мові, оскільки представлені лише одним фразеологізмом. Наприклад, структурна модель Adj. + V + Prep + N, у якій стрижневий прикметник вживається 3 додатковими елементами, зокрема 3 дієсловом, прийменником та іменником, наприклад: англ. able to talk under water 'дуже балакучий'.

2.1.2.2.5 Структурна модель Adj. + N + Prep. + NP має у складі іменникову групу, виражену прикметником та іменником: англ. not worth a cup of cold water 'нічого не вартий'.

2.1.2.2.6 Найбільшу кількість компонентів у складі серед ФО з лексичним компонентом «water» має структурна модель NP + NP + Conj. + N + Prep. + N, представлена фразеологізмом англ. Grantham gruel-nine grits and a gallon of water 'перебільшуючий дрізязкове та применшуючий необхідне'.

2.1.2.2.7 Найпродуктивнішою структурною моделлю некомпаративних ад’єктивних ФО 3 лексичним компонентом «вода» в українській мові є Conj. + N + V, наприклад: укр. хоч 3 лиия води напийся 'дуже гарний', хоч водою розливай 'дуже дружні', хоч воду пий 'красивий'. Цій групі притаманно надавати характеристику об’єкту імпліцитно, не використовуючи прикметник чи дієприкметник, як і для багатьох компаративних ад’єктивних ФО. Ця група є аломорфною, оскільки англійській мові не характерно вживання сполучника на початку фрази.

2.1.2.2.8 Найкоротшою за обсягом є структурна модель структурна модель $\mathbf{A d j} .+\mathbf{N}$, представлена двома синонімічними фразеологізмами укр. чистої води та чистісінької води, що означають 'справжній'. Незважаючи на «компактність» даної моделі, вона є непродуктивною серед ФО з лексичним компонентом «вода» в українській мові.

2.1.2.2.9 Найменш продуктивні структурні моделі ФО з лексичним компонентом «вода» в українській мові представлені одним фразеологізмом. Наприклад структурна модель Conj. + V + N, укр. не розлий вода 'дуже дружні'.

2.1.2.2.10 До групи Conj. + Prep. + N + V належить фразеологізм укр. хоч з лиця води напийся 'дуже гарний'.

2.1.2.2.11 Структурна модель Prep. + NP + V представлена висловом укр. в ложиі води не спіймаєм 'дуже спритний'.

Структурні моделі ад’єктивних некомпаративних ФО з компонентом «вода» в українській мові та «water» в англійській мові, а також їх відсоткове співвідношення представлені у Таблиці 3. 


\section{Структурні моделі ад’сктивних некомпаративних ФО з лексичним компонентом} «вода» в українській мові та «water» в англійській мові

\begin{tabular}{|l|l|l|l|}
\hline \multicolumn{1}{|c|}{ № } & \multicolumn{1}{c|}{ Структурні моделі } & \multicolumn{1}{c|}{ Англійська мова } & \multicolumn{1}{c|}{ Українська мова } \\
\hline 2.1 .2 .2 .1 & Part. / Adj. + Prep. + Конверсія & $3(27,28 \%)$ & $1(10 \%)$ \\
\hline 2.1 .2 .2 .2 & V + V + NP + Prep. + N / NP & $3(27,28 \%)$ & - \\
\hline 2.1 .2 .2 .3 & Prep. + N / NP & $2(18,19 \%)$ & - \\
\hline 2.1 .2 .2 .4 & Adj. + V + Prep + N & $1(9,09 \%)$ & - \\
\hline 2.1 .2 .2 .5 & Adj. + N + Prep. + NP & $1(9,09 \%)$ & - \\
\hline 2.1 .2 .2 .6 & NP + NP + Conj. + N + Prep. + N & $1(9,09 \%)$ & - \\
\hline 2.1 .2 .2 .7 & Conj. + N + V & - & $4(40 \%)$ \\
\hline 2.1 .2 .2 .8 & Adj. + N & - & $2(20 \%)$ \\
\hline 2.1 .2 .2 .9 & Conj. + V + N & - & $1(10 \%)$ \\
\hline 2.1 .2 .2 .10 & Conj. + Prep. + N + V & - & $1(10 \%)$ \\
\hline 2.1 .2 .2 .11 & Prep. + NP + V & - & $1(10 \%)$ \\
\hline Paзом & & $11(100 \%)$ & $10(100 \%)$ \\
\hline
\end{tabular}

Некомпаративні ад’єктивні ФО з компонентом «вода» в українській мові та «water» в англійській мові є досить нечисленними, однак структурно різноманітними. Ізоморфною рисою аналізованих фразеологізмів $є$ те, що 54,55 \% англійських ФО та 90 \% українських ФО мають імпліцитну основу ад'єктивної ознаки. Преважна більшість їхніх структурних моделей є аломорфними, що може пояснюватися відмінностями у граматичних правилах сполучуваності слів. Оскільки англійська мова синтетична, відношення між словами виражається завдяки прийменникам, натомість в українській мові подібне відношення висловлюється завдяки систем і відмінків. Крім того, в англійській мові некомпаративні ад'єктивні вислови не можуть починатися сполучником, що допускається в українській мові.

Проаналізувавши ад’єктивні ФО з лексичним компонентом «вода» в українській мові та «water» в англійській мові, можна стверджувати, що компаративні фразеологізми є продуктивнішими в обох аналізованих мовах, ніж некомпаративні. Надаючи характеристику об'єкту, ад'єктивні ФО порівнюють його з певним еталоном, добре відомим адресату, типовим носієм важливої для мовця ознаки, щоб слухач міг краще зрозуміти властивості даного об'єкту. Кількісне співвідношення ад'єктивних ФО з лексичним компонентом «вода» в українській мові та «water» в англійській мові зображений у Таблиці 4.

Таблиия 4

Види ад’єктивних ФО з лексичним компонентом «вода» в українській мові та «water» в англійській мові

\begin{tabular}{|c|c|c|}
\hline Ад’єктивні ФО & Англійська мова & Українська мова \\
\hline Компаративні ФО & $24(68,57 \%)$ & $15(60 \%)$ \\
\hline Некомпаративні ФО & $11(31,43 \%)$ & $10(40 \%)$ \\
\hline Разом & $35(100 \%)$ & $25(100 \%)$ \\
\hline
\end{tabular}

2.1.3 Субстантивні ФО з компонентом «вода» в українській мові та «water» в англійській мові. Відповідно до твердження М.Ф. Алефіренко, субстантивні фразеологізми - це «... фраземи з узагальнено-предметною семантикою, об'єктивованою в граматичних категоріях роду, числа й відмінка. У реченні субстантивні фраземи виконують синтаксичні функції 
підмета, іменної частини складеного присудка або додатка» (Алефіренко, 1987, с. 46). Дослідивши емпіричний матеріал субстантивних ФО з лексичним компонентом «вода» в українській мові та «water» в англійській мові, автором було виявлено, що в англійській мові ця група значно численніша, ніж у українській. Прикладами таких ФО є англ. bread and water 'найнеобхідніші засоби для існування', high water 'наявні достатні кошти', watering hole 'таверна', uncharted waters 'сфера для досліджень або методи, щодо яких немає інформації, укр. грішна вода 'горілка', десята вода на киселі 'далекі родичі' та інші. В результаті аналізу виявлено 7 структурних моделей ФО з компонентом «water» в англійській мові та 2 структурні моделі ФО $з$ компонентом «вода» в українській мові.

2.1.3.1 Найчисленніша ізоморфна група субстантивних ФО аналізованих мов - структурна модель N / NP + Prep. + N / NP що $€$ також найпродуктивнішою моделлю англійської мови, представлена словосполученнями, що мають у складі принаймні два іменники, поєднані між собою прийменниками (в англійській та українській мовах) та іменниками у родовому відмінку (лише в українській мові). Прикладами таких ФО є: англ. a drop of water on a hot stove 'щось корисне, але малоефективне', a tall drink of water 'дуже висока людина', water under the bridge 'щось давно минувше та забуте', укр. буря у склянці води 'суперечки через дрібниці', товчіння / товчення води в ступі ‘марнування часу' та інші.

2.1.3.2 Ще одна ізоморфна група, однак менш продуктивна - це структурна модель Adj. + (Adj.) + N, що відображає атрибутивний зв'язок між прикметником і іменником: англ. clear blue water, 'відмінність у політиці двох конкуруючих партій', smooth water 'умови, що дозволяють легкий прогрес', укр. грішна вода 'горілка'.

2.1.3.3 Аломорфною групою субстантивних ФО з лексичним компонентом «water» в англійській мові є структурна модель $\mathbf{N}+\mathbf{N}$, наприклад: water torture 'щось невинне, що стає нестерпним через постійне повторення', high-water mark 'найвищий рівень чогось, період розквіту’. Конверсія є типовим і набагато більш частотним явищем в англійській мові, ніж в українській, тому премодифікація іменника іншим іменником автоматично надає останньому атрибутивного значення. В українській мові подібне атрибутивне значення реалізується завдяки використанню іменника в родовому відмінку, однак субстантивних ФО з лексичним компонентом «вода» в українській мові подібної структурної моделі не виявлено.

2.1.3.4 Навідміну від попередніх моделей структурна модель $\mathbf{N}+\mathbf{C o n j}$ + $\mathbf{N}$ має у складі однорідні елементи, що з'єднані сполучником and. Наприклад: англ. bread and water 'мінімальні засоби для існування', oil and water 'несумісні елементи'. Можна припустити, що непродуктивність аналізованої структурної моделі пояснюється невеликим переліком слів, що можна вживати як однорідний елемент поряд з водою, оскільки важко знайти об'єкти, настільки ж важливі та необхідні, як вода.

2.1.3.5 Особливістю структурної моделі Part. + N є наявність в складі дієприкметника, що виконує атрибутивну функцію. Наприклад: uncharted waters 'невідома галузь, яка не досліджувалась чи метод, який не застововувався', watering hole ‘бар, таверна'.

2.1.3.6 Найрозлогішою з ФО з лексичним компонентом «water» в англійській мові $€$ структурна модель $6 \mathbf{N}+$ Prep. + N + Conj. + N + Prep + N, прикладом якої є англ. hewers of wood and drawers of water 'працівники різних професій'. Можна припустити, що це об'ємніше версія попередньої структури $\mathbf{N}+\mathbf{C o n j} .+\mathbf{N}$, у якій однорідні елементи виражені не одним сло- 
вом, а словосполученням, де атрибутивний зв'язок реалізується завдяки іменнику та прийменнику, що відображає відношення між іменниками.

2.1.3.7 Аломорфною групою, типовою лише для англійської мови є структурна модель $\mathbf{N P}+\mathbf{V}+\mathbf{A r t} .+\mathbf{N}$, що представлена фразеологізмом англ. enough water to sink a battleship 'велика кількість води'. Можна припустити, що непродуктивність даної структури обумовлена тим, що дієслово рідко виступає засобом реалізації атрибутивної функції. У результаті емпіричного матеріалу не виявлено жодного субстантивного ФО з компонентом «вода» в українській мові, що мав би у складі дієслово.

Кількісний склад структурних моделей субстантивних ФО з лексичним компонентом «вода» в українській мові та «water» в англійській мові представлений у Таблиці 5.

Таблиия 5

\section{Структурні моделі субстантивних ФО з лексичним компонентом «вода» в українській мові та «water» в англійській мові}

\begin{tabular}{|l|l|l|l|}
\hline \multicolumn{1}{|c|}{ № } & Структурні моделі субстантивних ФО & Англійська мова & Українська мова \\
\hline 2.1 .3 .1 & N / NP + Prep. + N / NP & $11(44 \%)$ & $4(80 \%)$ \\
\hline 2.1 .3 .2 & Adj. + N / NP & $2(8 \%)$ & $1(20 \%)$ \\
\hline 2.1 .3 .3 & N + N & $5(20 \%)$ & - \\
\hline 2.1 .3 .4 & N + Conj. + N & $3(12 \%)$ & - \\
\hline 2.1 .3 .5 & Part. + N & $2(8 \%)$ & - \\
\hline 2.1 .3 .6 & N + Prep. + N + Conj. + N + Prep + N & $1(4 \%)$ & - \\
\hline 2.1 .3 .7 & NP + V + Art. + N & $1(4 \%)$ & - \\
\hline Paзом & $25(100 \%)$ & $5(100 \%)$ \\
\hline
\end{tabular}

Як видно з таблиці, субстантивні ФО з компонентом «вода» в українській мові та «water» в англійській мові мають як ізоморфні, так і аломорфні структурні моделі, однак англійські фразеологізми значно чисельніші та різноманітніші, що може свідчити про більшу варіативність англійської мови у домені евфімізації та поетизації понять та об'єктів із залученням лексичного компоненту «water» до складу фразеологізмів порівняно з українською лексемою «вода».

2.1.4. Адвербіальні фразеологізмиз компонентом «вода» в українській мові та «water» в англійській мові. Згідно з твердженням М. Ф. Алефіренко, адвербіальні фразеологізми - це «фраземи кількісно- або якісно-обставинної семантики, які характеризуються повною відсутністю морфологічних парадигм і виконують у реченні функції обставин» (Алефіренко, 1987, c. 62). Кількісний склад ФО з лексичним компонентом «вода» в українській мові та «water» в англійській мові значно відрізняється. В українській мові виявлено 24 фразеологізми вказаної групи, які поділяються на 6 структурних моделей та 12 ФО в англійській мові, що мають 5 структурних моделей, три з яких є ізоморфними. Таку значну різницю, можливо б було пояснити тим, що українські фразеологічні словники часто подають подібні вирази без дієслова, а ряд дієслів, що можуть вживатися з такими словосполученнями зазначаються як можливі колокації. Наприклад: укр. як риба у воді може використовуватися з такими дієсловами, як почуватися, поводитися; укр. як камінь у воду - пропасти, зникнути та інші. Натомість англійські словники зазначають синонімічні дієслова, що можуть вживатися з подібними виразами як частину фразеологізму.

2.1.4.1 У результаті аналізу виявлено, що ізоморфні групи ФО з лексичним компонентом «вода» в українській мові та «water» в англійській мові досить непродуктивні. Наприклад, 
структурна модель Prep. + N + Conj. + N / NP представлена такими ФО: англ. between hell and high water 'у важкому становищі', between wind and water 'у найвразливішому місці', укр. в вогонь $i$ воду 'на будь-який самовідданий вчинок (іти, бути готовим)'. Як видно з прикладів, в обох аналізованих мовах використовуються сполучники, прийменники та іменники для вираження адвербіального значення.

2.1.4.2 Ще одна ізоморфна група - це структурна модель Conj. + N / NP, наприклад like water 'безрозсудно', укр. як воду 'у великій кількості (пити)', як чорт свяченої води 'дуже, сильно (боятися)’. Фразеологізми цієї групи досить невеликі за обсягом, однак аналізована група $€$ непродуктивною. Можливо, як і випадку з ад'єктивними ФО, причина нечисленності таких фразеологізмів пов'язана з тим, що у аналізованих лексем відсутня основа порівняння, яка опускається лише у найчастотніших порівняннях.

2.1.4.3 У результаті аналізу виявлено, що найчисленніша з структурних моделей в англійській мові - це структурна модель Рrep. + N / NP. Прикладами таких ФО є англ. in shoalwater off 'небезпечно поряд 3', in low water 'у скруті, у хворобі,' in rough water 'у біді', over the shoal-water 'подолавши труднощі', in smooth water 'за гарних обставин, особливо після скрути' та інші.

2.1.4.4 Найменш продуктивною в англійській мові є структурна модель Conj. + NP + Prep. + NP, наприклад англ. neither pot broken nor water spilt 'не заподіявши жодної шкоди'.

2.1.4.5 У результаті аналізу виявлено, що найчисленніша з адвербіальних ФО з лексичним компонентом «вода» в українській мові - це структурна модель Conj. + Prep. + NP, наприклад: укр. як в решеті води 'дуже мало', як з гусака вода 'ніщо не впливає', ні за холодну воду 'нічим не займаючись' та інші. Можливо це пояснюється тим, що ці фразеологізми є компаративними, вони актуалізують адвербіальне, порівнюючи їі з іншим, відомим носію мови.

2.1.4.6 Структурна модель Conj. + N + Prep. + N представлена такими ФО як укр. $i$ кінці y воду 'не залишаючи слідів', як лист за водою 'безслідно, назавжди', як пугою по водi 'безрезультатно’ та інші. Ця компаративна група подібна до попередньої, але реалізує адвербіальне відношення одного іменника стосовно іншого за допомогою прийменника.

2.1.4.7 Дещо менш продуктивна структурна модель Conj. + (V) + Prep. + N + (V), наприклад: укр. як плюнути на воду 'дуже легко', хоч у воду стрибай 'у безвиході'. Як уже зазначалося, дієслова рідко функціонують у складі ФО, що не належать до дієслівного розряду фразеологізмів.

2.1.4.8 До структурної моделі Conj. / Adv. + Prep. + N + Prep. + N належать синонімічні ФО, що мають значення 'у важкому становищі', наприклад: укр. хоч з гори та в воду, краще (все одно, щзо) з мосту та в воду.

2.1.4.9 Найменш продуктивні адвербіальні ФО з лексичним компонентом «вода» в українській мові - це структурна модель $\mathbf{N}+\mathbf{C o n j .}+\mathbf{V}$, що реалізується фразеологізмом укр. водою не розлити 'дуже дружно'.

2.1.4.10 Структурна модель Prep. + N + Conj. + N, представлена ФО укр. в вогонь $i$ воду 'на будь-який самовідданий вчинок (іти, бути готовим)'.

Кількісний склад адвербіальних структурних моделей ФО з лексичним компонентом «вода» в українській мові та «water» в англійській мові представлений у Таблиці 6. 


\section{Структурні моделі адвербіальних ФО з лексичним компонентом} «вода» в українській мові та «water» в англійській мові

\begin{tabular}{|l|l|l|l|}
\hline \multicolumn{1}{|c|}{ № } & \multicolumn{1}{|c}{ Структурні моделі адвербіальних ФО } & Англійська мова & \multicolumn{1}{|c|}{ Українська мова } \\
\hline 2.1 .4 .1 & Prep. + N + Conj. + N / NP & $2(16,67 \%)$ & $1(4,16 \%)$ \\
\hline 2.1 .4 .2 & Conj. + N / NP & $1(8,34 \%)$ & $2(8,34 \%)$ \\
\hline 2.1 .4 .3 & Prep. + N / NP & $7(58,34 \%)$ & - \\
\hline 2.1 .4 .4 & Conj. + NP + Prep. / Conj. + NP & $2(16,67 \%)$ & - \\
\hline 2.1 .4 .5 & Conj. + Prep. + NP & - & $7(29,18 \%)$ \\
\hline 2.1 .4 .6 & Conj. + N + Prep. + N & - & $6(25 \%)$ \\
\hline 2.1 .4 .7 & Conj. + (V) + Prep. + N + (V) & - & $3(12,5 \%)$ \\
\hline 2.1 .4 .8 & Conj. / Adv. + Prep. + N + Prep. + N & - & $3(12,5 \%)$ \\
\hline 2.1 .4 .9 & N + Conj. + V & - & $1(4,16 \%)$ \\
\hline 2.1 .4 .10 & Prep. + N + Conj. + N & - & $1(4,16 \%)$ \\
\hline Рaзом & & $12(100 \%)$ & $24(100 \%)$ \\
\hline
\end{tabular}

Як видно з таблиці адвербіальні ФО з лексичним компонентом «вода» в українській мові та «water» в англійській мові мають як ізоморфні, так і аломорфні структурні моделі. Українські адвербіальні фразеологізми вдвічі численніші, що може пояснюватися як більш поширеною практикою висловлювання адвербіальних відношень за допомогою ФО, так і різними підходами до укладання фразеологічних словників у аналізованих мовах, оскільки фразеологізми, що можуть вживатися з різними дієсловами фіксуються в українських словниках як адвербіальні, вказуючи дієслова як можливі колокації. Натомість англійські фразеологічні словники вказують подібні ФО як дієслівні, зазначаючи можливі лексичні варіанти таких фразеологізмів.

У результаті проведеного аналізу ФО рівня словосполучення 3 компонентом «вода» в українській мові та «water» в англійській мові виявлено такі семантико-граматичні розряди як субстантивні, ад’єктивні, дієслівні та адвербіальні. Їх кількісний розподіл ФО представлений у Таблиці 7.

Таблиия 7

ФО 3 компонентом «вода» в українській мові та «water» в англійській мові рівня словосполучення

\begin{tabular}{|l|l|l|}
\hline Семантико-граматичні розряди & \multicolumn{1}{|c|}{ Англійська мова } & \multicolumn{1}{c|}{ Українська мова } \\
\hline Дієслівні ФО & $92(56,1 \%)$ & $62(53,91 \%)$ \\
\hline Ад’єктивні ФО & $35(21,34 \%)$ & $24(20,87 \%)$ \\
\hline Субстантивні ФО & $25(15,24 \%)$ & $5(4,35 \%)$ \\
\hline Адвербіальні ФО & $12(7,32 \%)$ & $24(20,87 \%)$ \\
\hline Разом & $164(100 \%)$ & $115(100 \%)$ \\
\hline
\end{tabular}

Отже, найпродуктивнішими семантико-граматичними розрядами ФО з компонентом «вода» в українській мові та «Water» в англійській мові рівня словосполучення в обох досліджуваних мовах є дієслівні та ад’єктивні фразеологізми, їхня відносна кількість майже збігається, що може свідчити про подібність використання фразеологізмів для характеристики об'єктів, а також їхніх дій. Однак кількість субстантивних та адвербіальних ФО значно відрізняються. Значну кількість українських адвербіальних ФО частково можна пояснити різницею в підходах у лексикографічній практиці, оскільки українські лексикографи фіксують у фразеологічному словнику лише інваріативний вислів, зазначаючи у дужках можливі дієслівні коло- 
коції фразеологізму, натомість англійські науковці вказують лексичні варіанти фразеологізму 3 дієсловами, що сполучаються з сталими висловами. Велика кількість субстантивних ФО англійської мови може пояснюватися лінгвокультурологічними особливостями мовців, що схильні поетизувати та евфімізувати явища навколишнього світу.

2.2 ФО з компонентом «вода» в українській мові та «water» в англійській мові рівня речення. Поряд з фразеологізмами рівня словосполучення існують також ФО рівня речення. Вони, однак, не є найпродуктивнішою групою, оскільки для відтворення фразеологізму, що має розлогу структуру потрібно більше часу та зусиль, тому ФО рівня словосполучення видаються більш економними та легшими для запам'ятовування. Проте помітною є значна відмінність у відсотковому співвідношенні даних фразеологізмів на матеріалі дослідження: в англійській мові: в англійській мові це 86 (33,59\%), а в українській мові лише 16 (12,12\%). Це, насамперед, може бути зумовлене тим, що українські лексикографи не включають прислів'я у фразеологічні словники, на матеріалі яких здійснювалася вибірка, натомість англійська лексикографічна традиція допускає включення прислів'їв 3 певною позначкою у словниковій статті у фразеологічних словників.

Структура ФО рівня речення різноманітна, найпоширеніша - двоскладове речення: англ. blood is thicker than water 'родинні відносини важливіші за всі інші', англ. clean water often comes out of a mucky spout 'хороші діти можуть народитися у поганих батьків', англ. she has an eye in her head that would fetch a duck off the water 'дуже переконливий погляд', англ. where the dam is lowest the water first flows over' пристрасті вирують найбільше, коли є найменш контрольованими', укр. взяла вода 'хтось втопився', багато води упливло 'минуло багато часу з якоїсь пори’ та інші.

У структурі окремих англійських ФО спостерігається інверсія, що є відхиленням від звичних правил побудови речення: англ. from a pure spring, pure water flows 'хороші вчинки є результатом хорошого характеру'. Такий порядок слів підкреслює найважливіше у висловлюванні, змінюючи звичний для аналізованої мови порядок слів.

В англійській мові існують також еліптичні речення, де опущений і підмет, і присудок, але вони зрозумілі з структури речення: англ. nearest the well, furthest from water 'іноді ті, хто може легко щось зробити, нічого не робить'. У цьому випадку також важливий результат дій, а не виконавець, можливо саме тому і суб'єкт дії опускається, а увага зосереджується на наслідках певної поведінки.

Структурною особливістю ФО з компонентом «вода» в українській мові $є$ наявність безособових речень, що допускається її граматичними правилами, на відміну від англійської мови. Наприклад: укр. як линули холодною водою [з льодом] 'хтось дуже вражений', як водою вмило 'хтось швидко зник'.

Аломорфна модель ФО з компонентом «water» в англійській мові, характерна лише для англійської мови - це речення у наказовій формі: keep your dry rubs for your watery praturs 'турбуйся спочатку про себе та родину, а потім про інших', wade the water at shallowest 'справляйся з труднощами найлегшим способом', іноді такі речення можуть містити заперечну частку: cast not out the foul water till you bring in the clean 'використовуй те, що маєш доти, поки не отримаєш щось нове', don't pour water on a drowned mouse 'не виконуй непотрібну роботу', don't try to swim where there is no water 'для успішної роботи необхідні певні умови'. Це можна було б пояснити тим, що англійське суспільство більш регламентує поведінку його членів, 
вказуючи на неприйнятні моделі поведінки, закріплені не тільки у традиціях та звичках, а й у фразеологічних одиницях. Це своєрідний дидактичний прийом, спрямований на формування особистості, яку схвалює суспільство.

Кількісний розподіл ФО з компонентом «вода» в українській мові та «water» в англійській мові рівня речення представлений у Таблиці 8.

Таблиця 8

ФО $з$ компонентом «вода»в українській мові та «water в англійській мові рівня речення

\begin{tabular}{|l|c|c|}
\hline Види речень Мова & Англійська мова & Українська мова \\
\hline Двоскладові & $72(86,75 \%)$ & $8(50 \%)$ \\
\hline Односкадові & $11(13,25 \%)$ & $8(50 \%)$ \\
\hline Разом & $83(100 \%)$ & $16(100 \%)$ \\
\hline
\end{tabular}

Проведений аналіз дозволяє стверджувати, що в англійській мові переважають ФО рівня речення, які мають два члени речення, що є звичним способом побудови речень в обох досліджуваних мовах. Однак структурні типи одночленних речень не співпадають. В українській мові ФО з компонентом «вода»- це безособові речення, натомість в англійській мові цю структурну модель представляють наказові речення.

2.3 ФО лексичного рівня. Аломорфною групою англійської мови є наявність ФО лексичного рівня, значення яких не випливає з його складових частин, а є переосмисленим. В результаті аналізу виявлено чотири таких ФО з компонентом «water»: два фразеологізми, що функціонують як іменники: jerk-water 'неважлива особа', ebb-water 'нестача грошей'. Один ФО функціонує у мовленні як прикметник water-buffalo 'невибагливий', та один фразеологізм використовується як дієслово: to backwater 'відступати, 'залишати вже зайняті позиції. Наявність їх в англійській мові та відсутність в українській може бути зумовлена фразеологізацією композитів, які є більш продуктивним результатом словотвору в англійській мові у порівнянні 3 українською: чим продуктивнішими є мовні одиниці, тим більше шансів є того, що деякі 3 них можуть підпасти під процес фразеологізації. Крім того, традиційно фразеологічні словники української мови не включають об'єкти лексичного рівня, якими є композити, тому відсутність їх у матеріалі дослідження є законмірною.

Проведений аналіз ФО з компонентом «вода» в українській мові та «water в англійській мові дозволяє стверджувати, що ФО з компонентом «вода» в українській мові та «water» в англійській мові є одиницями різних рівнів: лексичного та синтаксичного, їх кількісне співвідношення представлене у Таблиці 9.

Вертикальне прочитання таблиці показує розподіл досліджуваних одиниць в кожній 3 мов, а також їх загальну кількість; горизонтально - типологію аналізованих ФО за їх рівнем вираження в мовах зі статистичними показниками. Закономірною є дуже низька продуктивність лексем в межах ФО (1,04 \%), адже сам статус фразеологізму передбачає обов'язкове поєднання слів, що суттєво зменшує кількість саме лексичних одиниць, здатних підпасти під процес фразеологізації. Відповідно, лише композити - лексеми за статусом - у випадку метафоризації чи метонімізації, та за умови закріплення в мовленнєвій практиці в переосмисленому значенні можуть претендувати на статус ФО. Найбільш сприятливим для формування ФО, 
як показує таблиця, є рівень словосполучення (73,04 \%), адже стабільність і відтворюваність колись вільних, а згодом семантично переосмислених, словосполучень перетворює їх складові на фраземотворчі компоненти, наповнюючи потужним емоційно-експресивним характером, але не позбавляючи при цьому усю ФО відносної гнучкості в плані здатності вступати в синтагматичні відношення. Речення займають проміжну позицію (25,92 \%), тому що з одного боку це завжди поєднання слів, що збільшує шанси на фразеологізацію у порівнянні з лексемою, але 3 іншого боку - це досить ємні утворення і структурно, і семантично, які вимагають більш складних когнітивних процесів, що знижує їх шанси на стабілізацію в мові та відтворюваність.

Таблиия 9

ФО 3 компонентом «вода»в українській мові та «water в англійській мові

\begin{tabular}{|c|c|c|c|c|c|}
\hline \multirow{2}{*}{ Рівень Мова } & \multicolumn{2}{|r|}{ Англійська мова } & \multicolumn{2}{|c|}{ Українська мова } & \multirow{2}{*}{ Разом } \\
\hline & Кількість & Приклад & Кількість & Приклад & \\
\hline Лексеми & $\begin{array}{c}4 \\
(1,59 \%) \\
\end{array}$ & $e b b$-water & - & - & $\begin{array}{c}4 \\
(1,04 \%) \\
\end{array}$ \\
\hline Словосполучення & $\begin{array}{c}164 \\
(65,34 \%) \\
\end{array}$ & to burn the water & $\begin{array}{c}115 \\
(87,79 \%) \\
\end{array}$ & линути холодною водою & $\begin{array}{c}279 \\
(73,04 \%) \\
\end{array}$ \\
\hline Речення & $\begin{array}{c}83 \\
(33,07 \%) \\
\end{array}$ & $\begin{array}{l}\text { Blood runs thicker than } \\
\text { water }\end{array}$ & $\begin{array}{c}16 \\
(12,21 \%)\end{array}$ & багато води утекло & $\begin{array}{c}99 \\
(25,92 \%)\end{array}$ \\
\hline Разом & $\begin{array}{c}251 \\
(100 \%)\end{array}$ & & $\begin{array}{c}131 \\
(100 \%)\end{array}$ & & $\begin{array}{c}382 \\
(100 \%)\end{array}$ \\
\hline
\end{tabular}

\section{3. Висновки}

Проведений аналіз засвідчує існування ізоморфних структурних моделей ФО з компонентом «вода» в українській мові та «water» в англійській мові, та аломорфних структур, що повністю відсутні у в одній з досліджуваних мов. ФО з компонентом «water» в англійській мові граматично різноманітніші та численніші, оскільки англійські фразеологізми можуть бути одиницями усіх трьох рівнів, натомість в українській мові існують ФО лише рівня словосполучення і речення. Найпродуктивнішими в обох досліджуваних мовах є ФО рівня словосполучення дієслівного, субстантивного, адвербіального та ад’єктивного розрядів, будучи когнітивно простішими за речення та більш сприятливими з позиції наявності необхідних умов для фразеологізації, ніж лексеми. Структурна різнорідність досліджуваних мов впливає на кількість і якість виокремлених типів фразеологічних одиниць. Зокрема неможливість препозиційного розташування додатка без інверсивного порядку слів в англійській мові виключає існування структурних типів, які починаються зі службових частин мови. Крім того, система відмінків в українській мові дозволяє виокремлення безприйменникових структурних іменникових типів, що є неможливим в англійській мові, в якій у таких випадках використовуються прийменники або конверсія іменника. Ізоморфною ознакою компаративних ФО в обох досліджуваних мовах $€$ імпліцитна основа порівняння, однак це більш притаманно українським фразеологізмам, у більшості яких основа порівняння опускається, однак легко розуміється носіями мови. Додатковою особливістю українських фразеологізмів з імпліцитно вираженою основою порівняння $\epsilon$ абсолютна однозначність експліцитно невираженої спільної ознаки порівнюваних явищ, в той час як в англійській мові імпліцитна основа порівняння може передбачати відкритий перелік потенційно можливих спільних ознак. 
Крім того, в межах матеріалу дослідження можна припустити, що представникам української лінгвоспільноти характерна більша прямолінійність, натомість англійці більш делікатні у висловлюваннях, використовуючи модальні дієслова, що роблять вислови менш категоричними, та суб'єктивними. Серед реченнєвих ФО з компонентом «вода» в українській мові та «water» в англійській мові найчисленнішими є двоскладові речення. Аломорфною структурою української мови є безособові речення, оскільки граматичні правила не дозволяють функціонування подібних структур в англійській мові. Натомість одночленні речення англійської мови представленні групою наказових речень, що повністю відсутні на матеріалі дослідження української мови. Подальші перспективи досліджень вбачаємо у зіставленні структур фразеологізмів з іншими компонентами, а також у вивченні культурних особливостей та мовної картини світу носіїв далеко споріднених мов.

\section{СПИСОК ЛІТЕРАТУРИ \\ (REFERENCES)}

Alefirenko, M. F. (1987). Teoretychni pytannia frazeolohii. Kharkiv: Vyshcha shkola.

Bilous, Yu. V. (2014). Komunikatyvno-prahmatychnyi potentsial frazeolohichnykh odynyts z somatychnym komponentom u nimetskii movi. Naukovyi visnyk Mizhnarodnoho humanitarnoho universytetu. Seriia: Filolohiia. Odesa.Vyp. 8, T. 1. S. 55-58.

Demskyi, M. T. (1984). Hramatychni osoblyvosti ukrainskoi diieslivnoi frazeolohii. Movoznavstvo. № 2. S. 24-32.

Zadorozhna, I. (2014). Nimetskomovni frazeolohichni odynytsi z komponentamy imennykamy "spaß", "gnade" ta "freude" (otsinnyi, emotyvno-ekspresyvnyi ta funktsionalno-stylistychnyi aspekty znachennia). Naukovyi visnyk Chernivetskoho universytetu. Hermanska filolohiia. Vyp. 708-709. S. 78-81.

Ighnatenko, D. Je. (2013). Frazeologhizmy na poznachennja intensyvnosti diji v anghlijsjkij ta ukrajinsjkij movakh // Studia Germanica et Romanica : Inozemni movy. Zarubizhna literatura. Metodyka vykladannja. Donecjk :DonNU. T. 10, № 2 (29). S. 57-68.

Kuchman, I. M. (2007). Dijeslivni frazeologhichni odynyci kauzatyvnoji semantyky z komponentom "chastyna tila". Naukovyj chasopys Nacionaljnogho pedaghoghichnogho universytetu imeni M. P. Draghomanova. Serija 10 : Problemy ghramatyky i leksykologhiji ukrajinsjkoji movy. Kyjiv : Vyd-vo NPU imeni M. P. Draghomanova. Vyp. 3. S. 211-219.

Lysenko, L. O. (2016). Kontrastyvnyi aspekt u vyvchenni frazeolohichnykh odynyts iz komponentom vohon (na materiali ukrainskoi ta anhliiskoi mov). Naukovi zapysky KDPU. Seriia: Filolohichni nauky (Movoznavstvo). Kirovohrad : Vydavets Lysenko V. F. Vyp. 146. S. 245-249.

Markova, D. (2017). Frazeolohizmy z komponentom sertse na poznachennia nehatyvnykh pochuttiv (na materiali ukrainskoi, polskoi, anhliiskoi ta nimetskoi mov). Naukovyi visnyk Skhidnoievropeiskoho natsionalnoho universytetu imeni Lesi Ukrainky. № 3. S. 113-117

Mizin, K. I. (2013). Ustaleni porivnjannja anghlijsjkoji, nimecjkoji, ukrajinsjkoji ta rosijsjkoji mov krizj pryzmu chasovogho kodu kuljtury: zistavno-linghvokuljturologhichnyj aspekt. Linghvistyka. № 2. S. 13-20. Rezhym dostupu:http://nbuv.gov.ua/UJRN/ling_2013_2_4 
Nikolaichuk, R. O. (2014). Frazeolohichni odynytsi iz komponentom «hroshova odynytsia» ta yikh tematychna klasyfikatsiia. Suchasni filolohichni doslidzhennia ta navchannia inozemnoi movy $v$ konteksti mizhkulturnoi komunikatsii. № 2. S. 96-101.

Soshko, O. H. (2013). Semantychni osoblyvosti komparatyvnykh frazeolohichnykh odynyts na poznachennia moralno-etychnykh rys liudyny (na materiali ukrainskoi, nimetskoi ta anhliiskoi mov). Mova i kultura. Vyp. 16, T. 3. S. 228-235. Rezhym dostupu: http://nbuv.gov.ua/UJRN/Mik_2013_ 16_3_38

Trocjuk, A. M. (2010). Strukturno-semantychni osoblyvosti Dijeslivnykh frazeologhichnykh odynycj iz somatychnym komponentom "hand". Nauk. visn. Volyn. nac. un-tu im. Lesi Ukrajinky. Serija: Filologhichni nauky. Vyp. 9, S. 396-399.

Khmara, V.V. (2015). Frazeolohizmy z somatychnym komponentom vukho v skhidnoslov'ianskykh ta zakhidnohermanskykh movakh: zistavnyi aspekt. Naukovi zapysky Natsionalnoho universytetu «Ostrozka akademiia». Ostroh: Natsionalnyi universytet «Ostrozka akademiia». S. 342-345.

Shchepka, O. (2011). Typolohiia komparatyvnykh frazeolohichnykh odynyts v ukrainskii i rosiiskii movakh: porivnialnyi aspekt. Linhvistychni studii. Vyp. 23. S. 211. 